Egyptian Journal of Aquatic Biology \& Fisheries

Zoology Department, Faculty of Science,

Ain Shams University, Cairo, Egypt.

ISSN $1110-6131$

Vol. 23(3): 263 - 270 (2019)

www.ejabf.journals.ekb.eg

\title{
Assessment of Short-term Effects of Pollution Accident on Fisheries in River Nile, Egypt
}

\author{
Walid Aly and Kariman A. Sh. Shalloof \\ Fisheries Biology Lab., Fisheries Department, National Institute of Oceanography and \\ Fisheries, Egypt \\ Corresponding Author: dr_kariman88@yahoo.com
}

\section{ARTICLE INFO \\ Article History: \\ Received: July 28, 2019 \\ Accepted: August 9, 2019 \\ Online: August 13, 2019}

Keywords:

River Nile

Tilapia

Pollution

Condition factor

Fisheries

\begin{abstract}
This study outlines the immediate impact on local fisheries of the incident that took place on $21^{\text {st }}$ April 2015. A barge capsized in the Nile in Upper Egypt's Qena governorate after colliding with the foundations of the city's Dandara Bridge. The capsized barge was carrying 500 tons of phosphate (pre-industrial, inert material) for processing in a local factory. The study aimed to record any apparent effect of the incident on the fisheries in the immediate site vicinity and downstream. Also, it described the status quo of the fisheries around the incident location to compare it with the situation before the accident to confirm any short-term impact and to establish a baseline for any future, long-term, impact studies. Data were collected on fish assemblage structure in the incident site vicinity, the number of fishing boats and fishing methods that were applied to catch them. Furthermore, some fisheries biological parameters were assessed. The main conclusions derived from the study were that fishing in the vicinity of the incident is artisanal with small boats and simple fishing gears. The fisheries biological parameters of the area's fishery are comparable to that of other similar environs, and that the incident did not have an apparent short term effect on the fishery profile of the area. The main recommendations resulted from this study were that the impact of the incident on fish at the molecular level should be studied and that the state of fisheries in the area should be followed up to detect any long-term impact of the incident.
\end{abstract}

\section{INTRODUCTION}

Egypt has about $8716 \mathrm{~km}^{2}$ of inland waters, including rivers, lakes, reservoirs and brackish water lagoons. Both commercial and sport fishing take place on these waters. The inland fishing fleet comprises over 23,158 small wooden boats (4-6 m in length) catching about 231,959 tonne, or 69 percent of Egyptian landings (GAFRD, 2018). Most of the fishermen are unregistered. There are about 270 registered landing sites and many unregistered (El-Bokhty and El-Far, 2014). The most economically important species are tilapia species (Oreochromis niloticus, O. aureus, Sarotherodon galilaeus, Tilapia zillii) and freshwater species (Bagrus bayad, Lates niloticus, Barbus spp., Clarias spp. and Mugil spp.) caught usually by trammel, cast and gillnets. The catch reached 231,959 tonne in 2016 (GAFRD, 2018).

The inland water resources represent various fisheries ecosystems. These include freshwater fisheries which comprises the River Nile, irrigation canals, and Lake Nasser, and some western desert water bodies. 
The River Nile extends for about $1600 \mathrm{~km}$, with two main branches downstream, and discharges to the Mediterranean Sea, with many small branches and canal covering a great area in the northern region of Egypt. During the last years, the recorded catch of the Nile River Basin in Egypt decreased from 110000 tonne in 2001 to 73,484 tonne in 2016 , with the catch comprising mainly tilapia and catfish from the artisanal fishing sector (GAFRD, 2018).

Qena Governorate is located in Upper Egypt north of Aswan Governorate and south of Sohag Governorate, its Capital is Qena City. Fisheries and Aquaculture contribute to Qena's economy. Artisanal fishing brings in an annual revenue of between LE 7,655,000 and LE 30,620,000 (EEAA, 2005).

On $21^{\text {st }}$ April 2015, a barge capsized in the Nile in Upper Egypt's Qena governorate after colliding with the foundations of the city's Dandara Bridge. The capsized barge was carrying 500 tons of phosphate (pre-industrial, inert material) for processing in a local factory.

This study aims to outline the immediate impact on local fisheries of the accident event of $21^{\text {st }}$ April 2015 through recording any apparent effect of the incident on the fisheries in the immediate site vicinity and downstream, and describing the status quo of the fisheries around the incident location to compare it with the situation before the accident (from previous literature) to confirm any shortterm impact and to establish a baseline for any future, long-term, impact studies.

\section{MATERIALS AND METHODS}

A field trip was carried out on $23^{\text {rd }}$ and $24^{\text {th }}$ April 2015 (two days after the incident) and covered Qena city area of the River Nile around the capsized barge. During the trip, data were collected on fish assemblage structure in the incident site vicinity, the number of fishing boats and fishing methods that were applied to catch them.

Samples of all available fish species in the incident site vicinity (190 specimen) were collected from five different sites (Fig. 1).

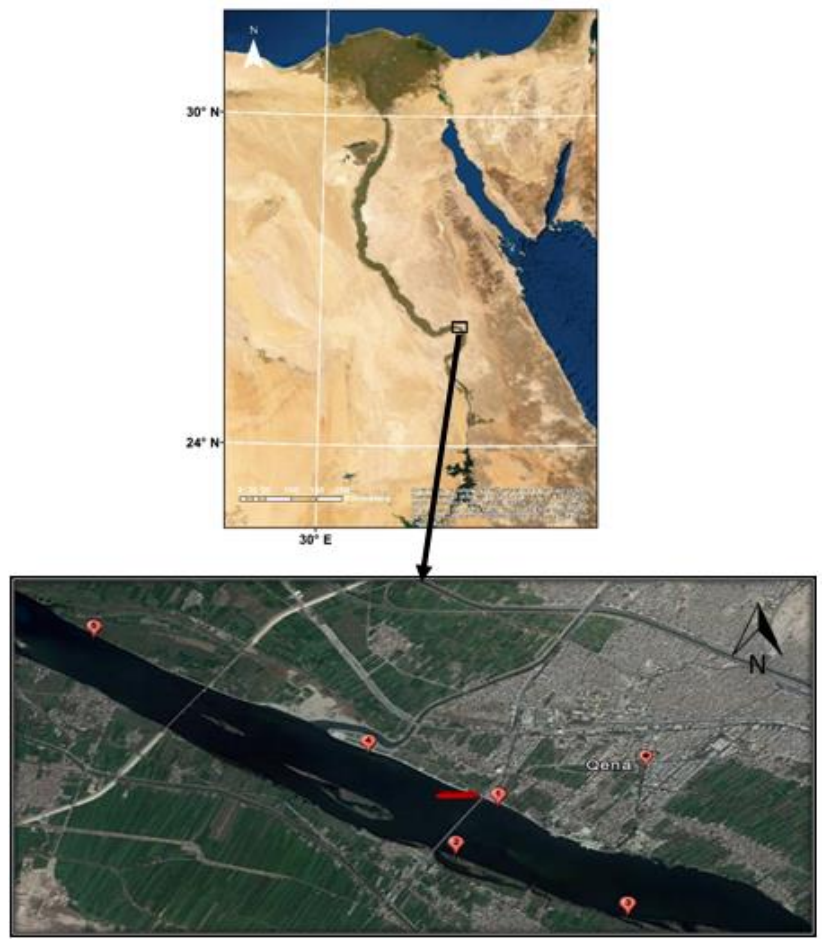

Fig.1: Maps showing the location of the capsized barge and samples collection sites 
a. Upstream: Site 1 on north-eastern bank of the river approximately 500 meters far from the capsized barge and sites 2 and 3 on the south-western bank which were approximately 800 and 3000 meters far from the capsized barge respectively.

b. Downstream: sites 4 and 5 on the north-eastern banks which were approximately 500 and 3000 meters far from the capsized barge respectively.

In laboratory, samples were firstly sorted into species to detect species composition, and then each specimen was measured to the nearest $0.1 \mathrm{~cm}$ and weighed to the nearest gram.

Length-weight relationship in fishes was applied and it can generally be expressed by the following equation: $\mathrm{W}=\mathrm{a} \mathrm{L}^{\mathrm{b}}$ (Le Cren, 1951), where $\mathrm{W}$ is the fish weight in grams, $\mathrm{L}$ is the body total length in $\mathrm{cm}$, $\mathrm{a}$ and $\mathrm{b}$ are constants.

In this study the Fulton's coefficient of condition $\left(\mathrm{K}_{\mathrm{c}}\right)$ was used, as it is the simplest and widely used formula for estimating this coefficient. It is as follows: $\mathrm{K}=$ $\left(\mathrm{W} / \mathrm{L}^{3}\right) \times 100$ (Pauly 1983), where $\mathrm{W}$ is total or gutted body weight $(\mathrm{g})$ and $\mathrm{L}$ is the total body length $(\mathrm{cm})$ of fish.

\section{RESULTS}

\section{Fishing methods and gears (Fig. 2): \\ Boats and fishers}

Boats in the vicinity of a capsized barge are made of wood and fitted with paddles. The boat length ranged from 4.25 to 5.5 meters and width ranged from 1.25 to 2.5 meters. Around 50 boats are fishing in the area and two fishermen operate each boat.

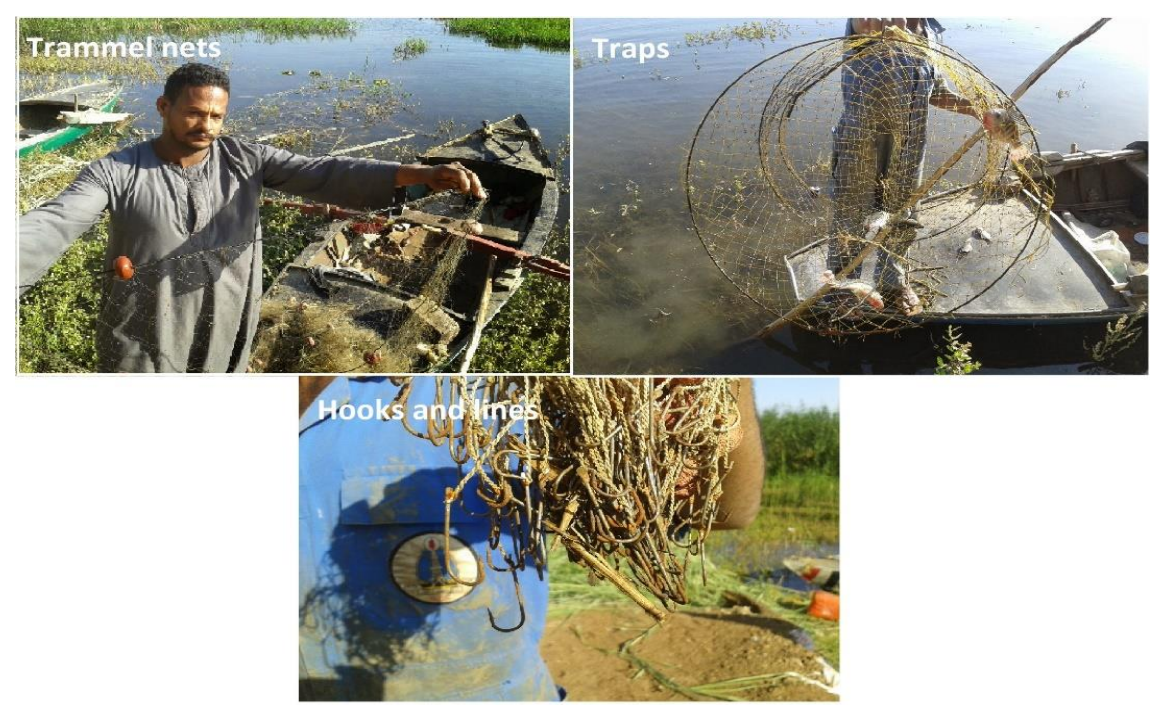

Fig. 2: Fishing gears in incident vicinity

\section{Trammel nets (tangling nets)}

Nets consist of three layers, two outer layers which are identical in height and mesh size and an inner layer which has smaller mesh size. The three layers are attached to floating line with crocks and lead line to grantee the horizontal extension of the net. Its length is around 50 meters with height of 1 meter and mesh size of the outer layers is $5.5 \mathrm{~cm}$ and of $2.5 \mathrm{~cm}$ for the inner layer. It is used in areas where water depth ranges between 1.5 to 2 meters. The net is used for fishing process once a day where it is spread before sunset to dawn the next day (about 12 hours). 


\section{Traps}

Round baskets made of steel wire covered with net with two large holes on the top and the bottom. It is placed next to the grass near the banks. Species caught are tilapia and other species.

The size of the large holes is ranging between 10 and $15 \mathrm{~cm}$. The mesh size is ranging from 2.25 to $2.50 \mathrm{~cm}$. Trapes are placed in the water in the sunset to dawn in depth ranges from 1.5 to 2 meters.

\section{Hooks and lines (Sennar)}

They are 50 metres-long lines twisted multifilament with size $11 \mathrm{~J}$-shape hooks. $15 \mathrm{~cm}$ between two successive hooks. Live bites, true hooks without bites also used. They are placed in the water in the sunset to dawn.

\section{Spatial variances in fishery profile}

Cluster analysis technique using Minitab@ 17 software was applied to classify the sampling sites with respect to their number of species, number of fish and average condition factor. Fig. (3) was obtained. The figure reveals that there is not distinctive difference between upstream sites (Q1, Q2 and Q3) and downstream sites (Q4 and Q5).

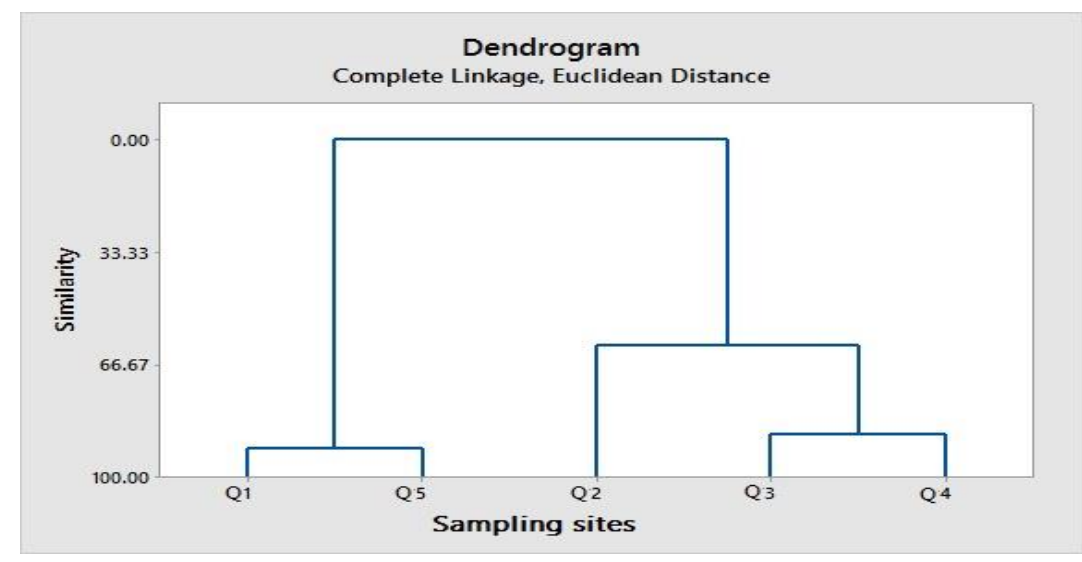

Fig. 3: Cluster of sampling sites based on number of species, number of fish and average condition factor.

\section{Species composition}

The fish catch from the incident site vicinity was comprised of three tilapia species namely; Oreochromis niloticus, Tilapia zillii and Sarotheredon galilaeus. In addition, the catch included specimens of Clarias gariepinus and Bagrus bayad, and one specimen of Oreochromis mossambicus. The pooled data (by number) revealed that $O$. niloticus was the most common species constituting about $48 \%$, followed by T. zillii (39\%), whereas S. galilaeus represented about $8 \%$ of the total catch. The least frequent species were B. bayad (3\%) and C. gariepinus (1\%). Species composition according to weight also ranked $O$. niloticus as the $1^{\text {st }}$ species (about 34 $\%$ of the total catch), whereas $T$. zillii is the $2^{\text {nd }}$ species, while $S$. galilaeus was the lowest one (Fig. 4). 


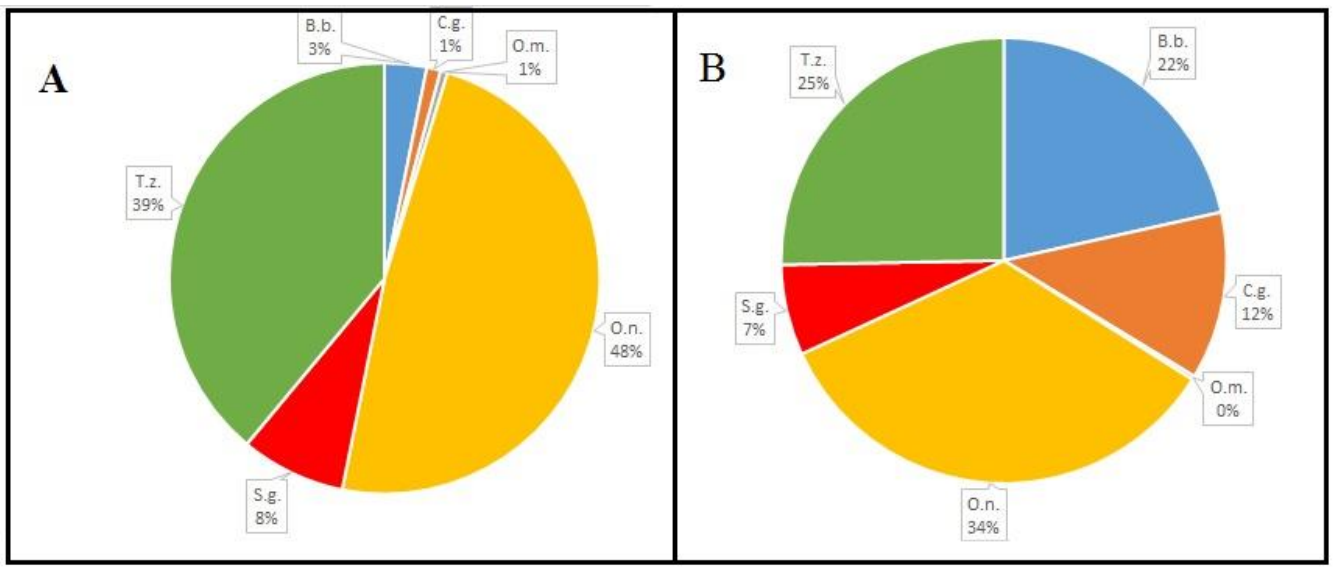

Fig. 4: Species composition of the catch from the incident site vicinity as number percentage (A) and weight percentage (B).

\section{Length-weight relationship}

Only two species have adequate number to apply this analysis, O. niloticus (92 specimens) and T. zillii (74 specimens). Figure 5 shows the output of the analysis. The value of (a) and (b) were 0.0174 and 3.0053 for $O$. niloticus and 0.0236 and 2.9387 for $T$. zillii which indicates that both species have isometric growth as (b) is close to 3 .

\section{Condition factor}

In the present study, total weight was used for calculating the condition factor $\left(\mathrm{K}_{\mathrm{c}}\right)$. The average $\mathrm{K}_{\mathrm{c}}$ for B. bayad, C. gariepinus, O. niloticusis, S. galilaeus and $T$. zillii were $0.56,0.88,1.77,2.04$ and 2.01 , respectively.

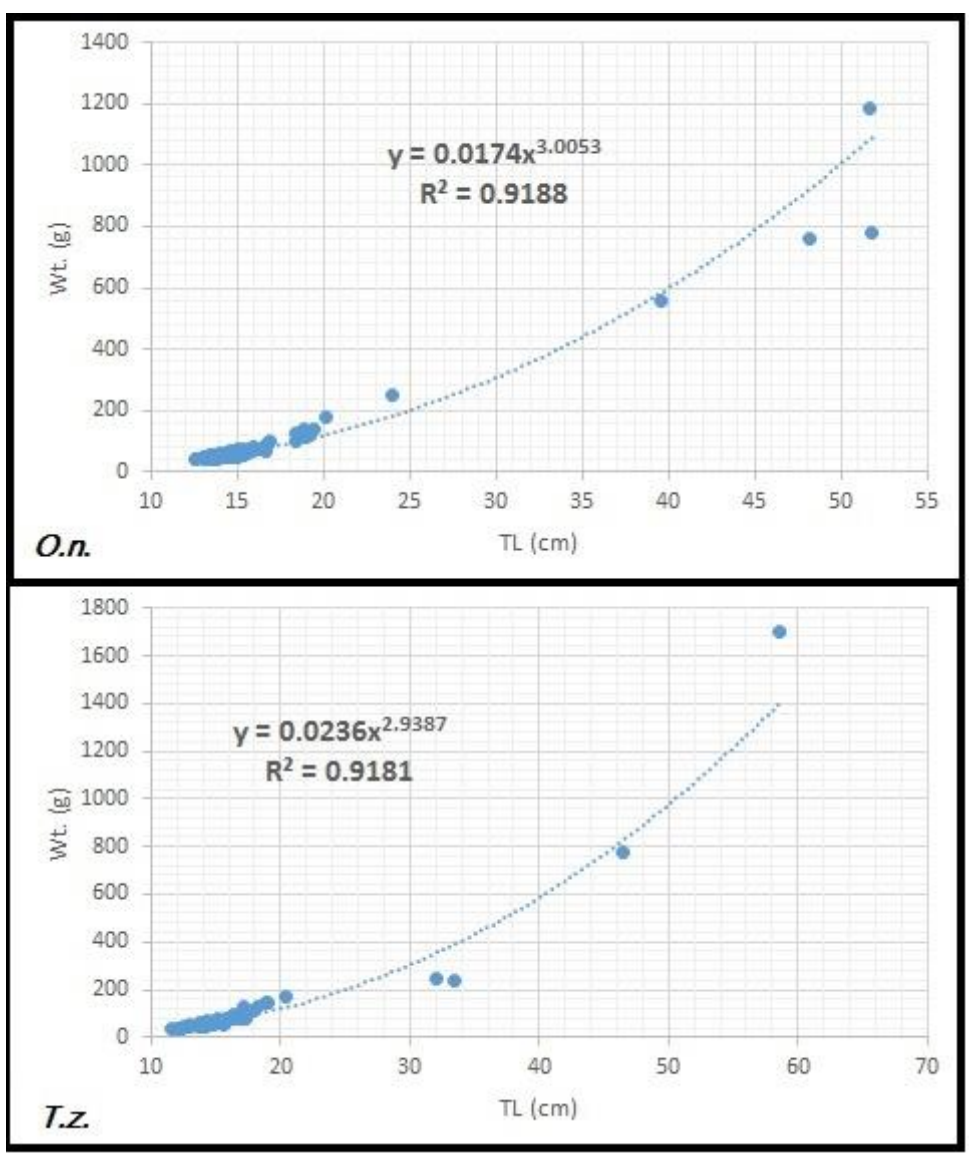

Fig. 5: Length-weight relationship of $O$. niloticus and T. zillii. 


\section{DISCUSSION}

Pollution effects on fisheries and the possible management activities that should be undertaken to reduce any demonstrated effects have always occupied the attention of fisheries scientists. They have to confront two responsibilities considering pollution effects on fisheries: one is to demonstrate that pollution is really affecting fish and stocks, and the second is to propose management measures to mitigate damage if it exists. These responsibilities can be satisfied in many stages, one of them is to conduct critical examinations of pollution effects at levels of the individual, the local population, and the species. However, the stress from chemical pollutants can have significant quantifiable effects on resource species abundance is much more difficult to demonstrate, and has not been documented satisfactorily (Sindermann, 1980).

This study is trying to outline the immediate impact on local fisheries of the incident that took place on $21^{\text {st }}$ April 2015. Where a barge capsized in the Nile in Upper Egypt's Qena governorate after colliding with the foundations of the city's Dandara Bridge. The capsized barge was carrying 500 tons of phosphate (preindustrial, inert material) for processing in a local factory.

The fishing in the vicinity of the incident are artisanal with small boats and simple fishing gears, however, according to the FAO's Advisory Committee on Fishery Research (ACFR) Working Group on Small-Scale Fisheries "small-scale fisheries make an important contribution to nutrition, food security, sustainable livelihoods and poverty alleviation, especially in developing countries" (FAO, 2012).

When examining the fishery profile upstream and downstream of the incident site, the results shows no distinctive difference (Fig., 3). According to fishery profile (number of species, number of fish and average condition factor) site Q1 (upstream) formed a distinctive group with site Q5 (downstream); while the other 3 sites ( Q2 and Q3 upstream and Q4 downstream) formed another group. Also, the fish catch from the incident site vicinity was comprised of the species that expected to be caught in this time of year (Shalloof and El-Far, 2010). This implies that the incident did not have an effect on the fishery profile of the area on the short term.

Knowledge of length-weight relationship of a fish species is an important biological tool in the management of fish population (Mendes et al., 2004). The study of length- weight relationship provides mathematical expiration between these two measurements as that one may be converted to the other (Richter et al., 2000). A fish is growing isometrically if the increasing in all dimensions at the same rate. The length-weight relationship is affected mostly by various factors such as, the availability of food, rate of feeding, spawning ...etc (Froese, 2006).

In the present study, the length- weight relationships were calculated for two Cichlid species $(O$. niloticus and $T$. zillii) show that the values of the constant "b" in both regressions were very close to three. This indicates that fishes grow almost symmetrically or isometrically in weight with length if its specific gravity remains constant which agree with the previous studies on these species in Egyptian waters (Ibrahim et al., 2007). Also, the result of this study agree with that of Shalloof and El-Far, (2017) who found in their study of length-weight relationship of some fishes from the River Nile that the value of (a) and (b) were 0.018 and 3.017 for $O$. niloticus and 0.019 and 2.997 for T. zillii.

The condition of a fish species is a measure of the degree of wellbeing, plumpness or fatness and is a function of several factors such as age, sex and season 
(Lagler, 1956). It is greatly affected by the quantity and quality of the available food as well as the environmental conditions of the water-body in which the fish lives.

The condition factor "Kc" has been widely used by fishing biologists to express the suitability of an environment to a certain species. It is also called the coefficient of condition or Ponderal index (Anene, 2005).

In the present study total weight was used for calculating the condition factor. It was noted that, for all species, the condition factor mostly varies slightly from species to another in the incident vicinity. Average condition factor for the species are close to these recorded for the same species. Shalloof and El-Far, (2017) reported in their study of condition factor of some fishes from the River Nile that the average $\mathrm{K}_{\mathrm{c}}$ for $B$. bayad, C. gariepinus, O. niloticusis, S. galilaeus and T. zillii were 0.954, 0.710, $1.919,2.006$ and 1.917, respectively which are comparable to that recorded in this study.

\section{CONCLUSION}

The main conclusions derived from the above results are that the fishing in the vicinity of the incident is artisanal with small boats and simple fishing gears, the fisheries biological parameters of the area's fishery are comparable to that of other similar environs, and the incident did not have an effect on the fishery profile of the area over the short term. The impact of the incident on fish at the molecular level should be studied, and the state of fisheries in the area should be followed up to detect any long-term impact of the incident.

\section{REFERENCES}

Anene, A. (2005). Condition factor of four Cichlid species of a man-made lake in Imo State, Southeastern Nigeria. Turkish Journal of Fisheries and Aquatic Sciences 5(1) :43-47.

EEAA (Ministry of State for Environmental Affairs) (2005). Qena Governorate Environmental Action Plan. Egyptian Environmental Affairs Agency, SEAM Programme, Entec UK Ltd., ERM.

El-Bokhty, E.E.B and El-Far, A. M. (2014). Some fishery aspects of Nile tilapia, Oreochromis niloticus at Rosetta branch of the Nile River, Egypt. Egyptian Journal of Aquatic Biology and Fisheries, 18(3):41- 51.

FAO (Food and Agriculture Organization of the United Nations). (2012). International Guidelines for Securing Sustainable Small-scale Fisheries. Zero Draft: $31 \mathrm{pp}$.

Froese, R. (2006). Cube law, condition factor and weight-length relationships: history, meta- analysis and recommendations. Journal of applied ichthyology, 22(4): 241-253.

GAFRD (2018). 2016 Fisheries statistics yearbook (General Authority for Fish Resources Development, Cairo, Egypt).

Ibrahim, M. A. ; El-Agamy, A. E. ; Awad, G. S. and Aly, W. E. (2007). Population dynamics and stock assessment of family Cichlidae in Lake Edku, Egypt. Journal of Egyptian German Society of Zoology. Vol (52D).Invertebrate Zoology and Parasitology:15-34.

Lagler, K.F. (1956). Freshwater fishery biology. 1st Ed. 421 pp. W.M.C. Brown Company, Dubuque, Lowa. 
Le Cren, E.D. (1951). The length-weight relationship and seasonal cycles in gonad weight and condition in the perch (Perca fluviatilis). J. Animal Ecol., 20 (2):1621.

Mendes, B.; Fonseca, P. and A. Campos (2004). Weight-length relationships for 46 fish species of the Portuguese west coast. Journal of Applied Ichthyology 20(5): 355-361.

Pauly D. (1983). Some simple methods for the assessment of tropical fish stocks. Food \& Agriculture Org.

Richter, H.; Luckstadt, C.; Focken, U. and Becker, K. (2000). An improved procedure to assess fish condition on the basis of length-weight relationships. Archive of Fishery and Marine Research 48(3): 255-264.

Shalloof, K. A. Sh. and El-Far, A. (2010). Population structure and catch per unit effort (CPUE) in the main stream, Rosetta and Damietta branches of the River Nile, Egypt. Egyptian Journal of Aquatic Research 36 (3): 435-443.

Shalloof, K.A. and El-Far, A.M., (2017). Length-Weight Relationship and Condition Factor of Some Fishes from the River Nile in Egypt with Special Reference to Four Tilapia Species. Egypt. J. Aquat. Biol. \& Fish., 21(2): 33- 46.

Sindermann, C. J. (1980). Pollution effects on fisheries-potential management activities. Helgoländer Meeresuntersuchungen, 33(1-4): 674-686.

\section{ARABIC SUMMARY}

$$
\begin{aligned}
& \text { تقييم الآثار قصيرة الأجل لحادث التلوث على مصايد الأسماك في نهز النيل ، مصر }
\end{aligned}
$$

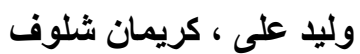

$$
\begin{aligned}
& \text { معمل بيولوجيا المصايد ، شعبة المصايد ، المعهد القومى لعلوم البحار و المصايد، مصر }
\end{aligned}
$$

توضح هذه الدراسة التأثير الفوري للحادث الذي وقع في 21 أبريل 2015 على مصائد الأسماك

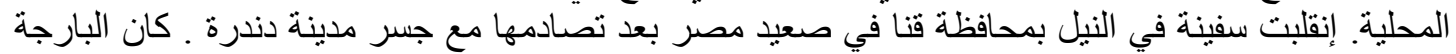

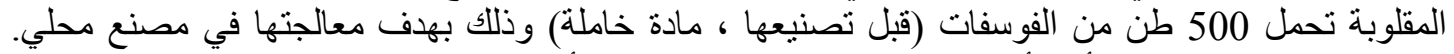

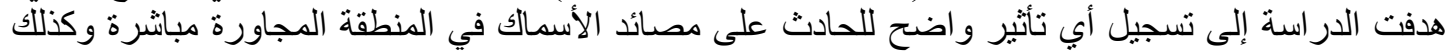

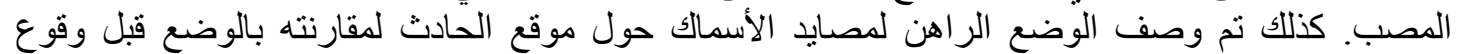

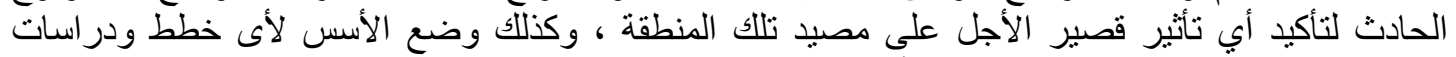

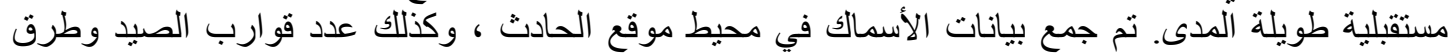

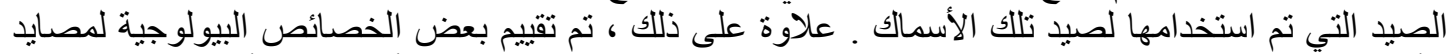

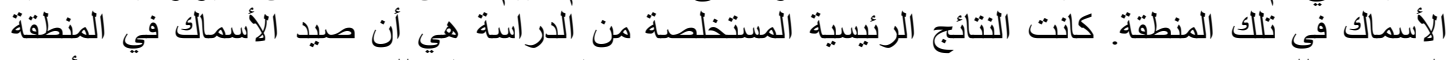

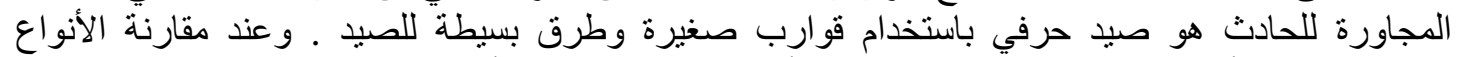

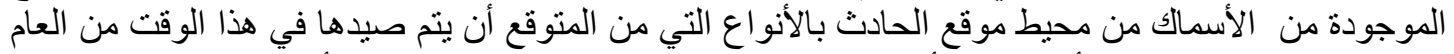

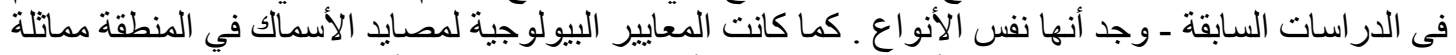

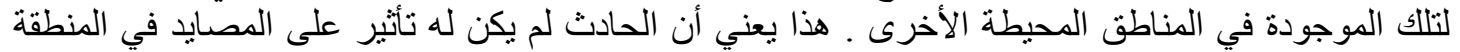

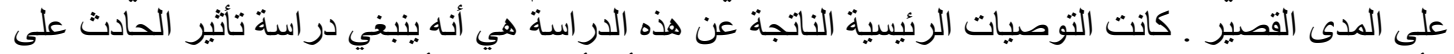

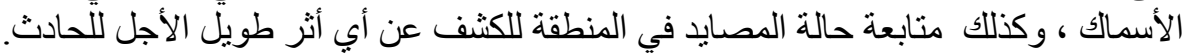

